\title{
Single chamber air-cathode microbial fuel cells as biosensors for determination of biodegradable organics
}

\author{
Bálint Lóránt • Miklós Gyalai-Korpos • Igor Goryanin · Gábor Márk Tardy
}

Received: 18 October 2018/Accepted: 26 March 2019/Published online: 3 April 2019

(C) The Author(s) 2019

\begin{abstract}
Objectives Single chamber air cathode microbial fuel cells (MFCs) were investigated with sodiumacetate and peptone as test substrates to assess the potential for application as biosensor to determine the concentration of biodegradable organics in water/ wastewater samples.
\end{abstract}

Results MFCs provided well-reproducible performance at high (>2000 mg COD $1^{-1}$-Chemical Oxygen Demand) acetate concentration values.

\section{B. Lóránt · G. M. Tardy $(\bowtie)$}

Department of Applied Biotechnology and Food Science, Budapest University of Technology and Economics, Szt. Gellért tér 4, Budapest 1111, Hungary

e-mail: gtardy@mail.bme.hu

\section{B. Lóránt}

e-mail: balintlorant99@gmail.com

M. Gyalai-Korpos

Pannon Pro Innovations Ltd, P.O.B 41, Budapest 1400,

Hungary

e-mail: miklos.gyalai@ppis.hu

M. Gyalai-Korpos

BES Europe Ltd, Murányi u. 39, Budapest 1078, Hungary

I. Goryanin

School of Informatics, University of Edinburgh, 10

Crichton str, Edinburgh EH8 9AB, UK

e-mail: goryanin@gmail.com
Current in the cells proved to be steady from 25 to $35{ }^{\circ} \mathrm{C}$, significant decrease was, however, revealed in the current below $20^{\circ} \mathrm{C}$. Direct calculation of nontoxic biodegradable substrate concentration in water/ wastewater from the current in MFCs is possible only in the non-saturated substrate concentration range due to the Monod-like dependence of the current. This range was determined by a fitted and verified Monodbased kinetic model. Half saturation constant $\left(\mathrm{K}_{\mathrm{S}}\right)$ values were calculated at $30^{\circ} \mathrm{C}$ applying different

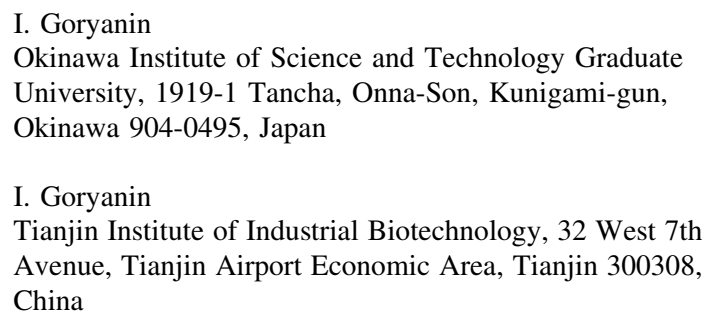


external resistance values $(100 \Omega, 600 \Omega$ and $1000 \Omega$, respectively). In each case $\mathrm{K}_{\mathrm{S}}$ remained below $10 \mathrm{mg}$ $\mathrm{COD}^{-1}$.

Conclusions Biosensors with this particular MFC design and operation are potentially applicable for

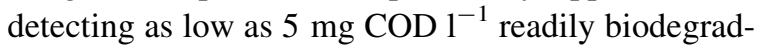
able substrates, and measuring the concentration of these substances up to $\sim 50-70 \mathrm{mg} \mathrm{COD}{ }^{-1}$.

Keywords Air cathode $\cdot$ Biosensor $\cdot$ Biodegradation kinetics $\cdot$ Microbial fuel cell

\section{Introduction}

Microbial fuel cells (MFCs) are special bioreactors that can convert the chemical energy stored in biodegradable substances directly into electricity. The operating principle of an MFC is based on the metabolism of exoelectrogenic bacteria: these organisms can transfer the electrons gained through biodegradation of organic compounds to the solid anode, thus generating electricity in the external circuit of the cell. MFCs have multiple fields of potential application: they can be implemented as energy-efficient wastewater treatment technologies or used as power source for portable devices with low energy demand (Fedorovich et al. 2009; Rahimnejad et al. 2015; Divyalakshmi et al. 2017). Yet, one of the most promising way of utilizing MFCs is the application as biosensors to detect biodegradable organics and/or toxic compounds even at extremely low concentrations (Abrevaya et al. 2015a, b; Sun et al. 2015).

The basic way of measuring the concentration of non-toxic biodegradable organic matter in water or wastewater with MFCs is based on the correlation between the generated current and substrate concentration in the anolyte, which can be described generally with Monod-like kinetics (Lóránt et al. 2015), as shown in Eq. 1.

$I=I_{\max } \frac{S}{K_{S}+S}$ where I is the measured current in the circuit of the cell $(\mu \mathrm{A}), \mathrm{I}_{\max }$ is the maximum current produced at high substrate concentrations $(\mu \mathrm{A}), \mathrm{S}$ is the bidegradable substrate concentration ( $\mathrm{mg} \mathrm{COD} \mathrm{l}^{-1}$ ) and $\mathrm{K}_{\mathrm{S}}$ is the half-saturation constant ( $\mathrm{mg} \mathrm{COD} \mathrm{l}^{-1}$ ).

Because of the saturation curve, direct determination of the substrate concentration in the anolyte by measuring current is possible only in the non-saturated substrate concentration range, therefore it is essential to know the value of the main parameter affecting the shape of the Monod curve: the half saturation constant $\left(\mathrm{K}_{\mathrm{S}}\right)$. Based on the literature, $\mathrm{K}_{\mathrm{S}}$ varies in a wide range (from $<1$ to $>100 \mathrm{mg} \mathrm{COD}^{-1}$ ), depending on the design and operation (Tront et al. 2008; Sharma and Li 2010; Tardy et al. 2017a). As a result, it is possible to develop MFC-based biosensors for working in trace amount of substrate concentration range $(0-150 \mu \mathrm{M}$ of acetate) (Quek et al. 2015), to higher organic matter content ( 3 to $164 \mathrm{mg} \mathrm{COD}^{-1}$ ) (Di Lorenzo et al. 2014).

Single chamber air cathode MFCs were assembled and investigated in this research applying noble metal free biomass originated air cathode materials to determine the potential of this design as a biosensor. Hydraulic and biokinetic model of the cells were developed, fitted and verified for the appropriate interpretation of the cell's electric response to substrate concentration changes.

\section{Materials and methods}

MFC architecture, data collection

The parts of the three single chamber air-cathode MFCs (see Fig. 1) applied in this study were developed and provided by the Okinawa Institute of Science and Technology Graduate University-Biological Systems Unit, Okinawa, Japan. The MFCs with an inner volume of $230 \mathrm{~cm}^{3}$ each were assembled from prefabricated PVC parts.

Graphite brushes with a diameter of $10 \mathrm{~cm}$ were used as anode. The proton exchange membranes (PEM) were porous ceramic plates with ion exchange polymer in the pores. The air-cathodes consisted of 3 layers. The first layer was a glassy carbon cloth that was immersed in distilled water during the whole operation time supplying the necessary aqueous 


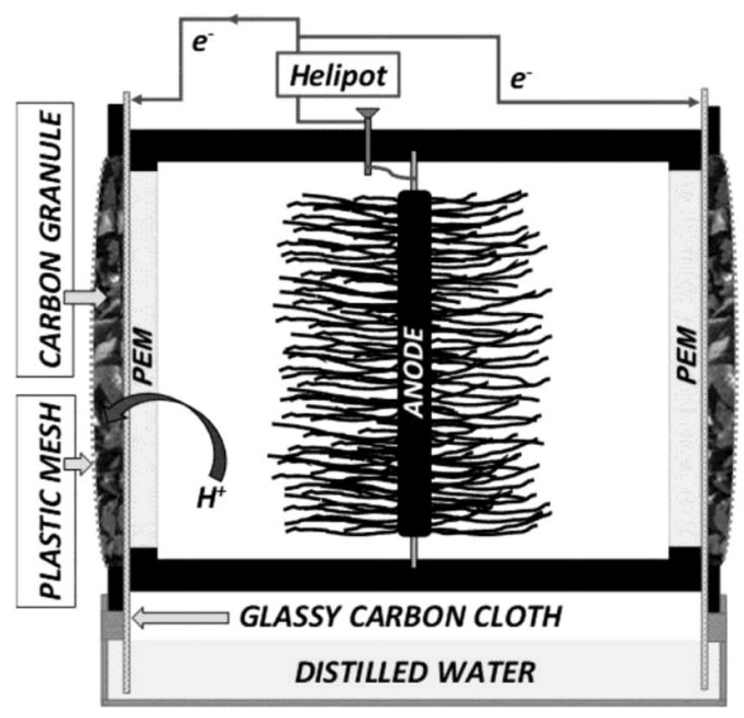

Fig. 1 Scheme of the applied MFCs

medium for the oxygen reduction reaction through capillary action, and also providing the dilution and removal of soluble contaminants (e.g. salts) possibly diffusing from the anode chamber through the ceramic layer. The current collecting wires were connected to this glassy carbon layer through titanium screws. The second layer of the air cathode was made of a new, patented, biomass-based renewable material: $25 \mathrm{ml}$ carbonized coconut shell granules (diameter cca. 2-4 mm) were applied based on Schaffer-Harris et al. 2017. The reduction of the oxygen takes place on the surface of these granules. Finally, a plastic mesh was applied to fix the other 2 layers and membrane surface together, maintaining the connection with the PEM. The geometrical contact surface of the PEM with the air cathode was $48 \mathrm{~cm}^{2}$. Each cell had two identical air cathodes on the two opposite sides that were connected in parallel. Two tube connection point for influent and effluent, as well as a sealable sampling hole were placed on the surface of the cell.

The electronic apparatus included the circuit, the adjustable external resistance (helipot, $0-10 \mathrm{k} \Omega$ ) and data collection device (Graphtec midi logger GL840 oscilloscope). Potential on the external resistor was measured and registered in every $20 \mathrm{~s}$. Electric parameters (current, power) were calculated from voltage values.

Anodic chambers of all three MFCs were connected hydraulically to the same 11 stirred buffer tank by plastic tubing with an inner diameter of $1.5 \mathrm{~mm}$, thus, the total liquid volume of the system was $1690 \mathrm{ml}$ not counting the negligible volume of the tubing. Circulation of the anolyte between the buffer tank and the anode chambers was provided by a peristaltic pump (Masterflex ${ }^{\circledR}$ ). MFCs and the buffer tank were kept in a thermostat (WTW 606) to maintain the desired temperature. During the whole research, the three MFCs (referred as Cell "A", Cell "B" and Cell "C") were operated under the same conditions in order to investigate the reproducibility of the results in parallel systems, and to be able to calculate basic statistics (e.g. standard deviation).

\section{MFC operation}

\section{Composition of the media}

During general operation, media in the anodic chamber and the buffer tank contained salt components as follows: $3.13 \mathrm{~g} \mathrm{l}^{-1} \mathrm{NaHCO}_{3}, 0.31 \mathrm{~g} \mathrm{l}^{-1} \mathrm{NH}_{4} \mathrm{Cl}$, $0.13 \mathrm{~g} \mathrm{l}^{-1} \mathrm{KCl}, 4.22 \mathrm{~g} \mathrm{l}^{-1} \mathrm{NaH}_{2} \mathrm{PO}_{4}, 6.93 \mathrm{~g} \mathrm{l}^{-1} \mathrm{Na}_{2}$ $\mathrm{HPO}_{4} \times 12 \mathrm{H}_{2} \mathrm{O}$ plus trace elements (based on $\mathrm{Oh}$ et al. 2004). Sodium-acetate or peptone (Molar chemicals) was added as carbon source. Standard concentration of the sodium acetate was $40 \mathrm{mM}$ (2550 $\mathrm{mg} \mathrm{COD}^{-1}$ ) during inoculation and basic investigation of the cell parameters (polarization measurements). To maintain anaerobic conditions, before introducing to the anode chamber, fresh media was de-oxygenated by heating up to $\sim 70{ }^{\circ} \mathrm{C}$ and then cooled down to room temperature while bubbling with $\mathrm{N}_{2}$ continuously.

\section{Inoculation}

Primary settled sludge from domestic wastewater treatment plant was used as inoculum. Before introducing to the anode chamber, it was diluted to $\sim 1 \mathrm{~g}$ TSS $1^{-1}$ (total suspended solids) with the salt solution described previously, containing $40 \mathrm{mM}$ acetate substrate. Anodic chambers and the buffer tank were filled with a total volume of $1690 \mathrm{ml}$ inoculating suspension, flow rate of the media between the buffer tank and each cell was $690 \mathrm{ml} \mathrm{h}^{-1}$, resulting in $20 \mathrm{~min}$ of hydraulic retention time. Within a $\sim 2$-weeks long inoculation period applying $1000 \Omega$ external resistance, the voltage increased and stabilized at $0.5-0.6 \mathrm{~V}$ in each cell. Having the voltage stabilized, 
the inoculating suspension was washed out with fresh media.

\section{Polarization measurements}

Polarization tests were carried out to determine the basic electric parameters of the cells (maximum power output, internal resistance). To eliminate the effect of a possible hysteresis, polarization tests were carried out first by increasing the adjustable external resistance from 0 to $10,000 \Omega$ in specified steps, after that, decreasing the resistance from 10,000 to $0 \Omega$ using the same steps. Polarization curves were obtained by calculating the average values for each external resistance.

\section{Determination of concentration dependence of the current}

Anode chambers of the MFCs were washed through with 41 of fresh de-oxygenated carbon source free media in order to reach substrate free conditions. 11 of the same, substrate free media was introduced to the buffer tank and circulated between the MFCs and the buffer tank. Because of substrate free operation, the potential of the cells decreased below $2-5 \mathrm{mV}$ (depending on the external resistance), which was considered to be the threshold value of endogenous metabolism in this experiment. Having reached the endogenous regime, stepwise increasing of the acetate concentration (thus increasing the available carbon source in the fuel cells) was carried out by the addition of small volumes (typically 1-4 ml) of high concentration (6500 mg COD $\mathrm{m}^{-1}$ ) sodium acetate solution to the stirred buffer tank. To guarantee the appropriate mixing of the increased acetate concentration media of the buffer with the media in the anodic compartments, flow rate between the buffer tank and each cell was adjusted to $1380 \mathrm{ml} \mathrm{h}^{-1}$, resulting in $10 \mathrm{~min}$ of hydraulic retention time in the anodic compartments during this experiment. Samples for acetate concentration measurements were collected from the anolyte at least 30 min following the acetate addition in order to provide the required time for the concentration equalization between the buffer and anode compartments of the MFCs.

Acetate concentrations from centrifuged $(19,000 \mathrm{~g}$, Hermle Z323) samples taken from the anolyte were measured by a Shimadzu gas chromatograph with flame ionization detector, AOC 22i automatic injector and Restek Stabilwax DA $30 \mathrm{~m} \times 0.32 \mathrm{~mm} \times$ $0.25 \mu \mathrm{m}$ capillary column. The initial column temperature was $100{ }^{\circ} \mathrm{C}$, that was increased by $10{ }^{\circ} \mathrm{C} / \mathrm{min}$ up to $210{ }^{\circ} \mathrm{C}$, then kept at $210{ }^{\circ} \mathrm{C}$ for $10 \mathrm{~min}$. Hydrogen was used as carrier gas with a flow rate of $50 \mathrm{ml} / \mathrm{sec}$. Temperature of FID was $280{ }^{\circ} \mathrm{C}$. 3-pointed calibration was used for quantitative determination.

\section{Results and discussion}

Performance characteristics of the MFCs at $30{ }^{\circ} \mathrm{C}$ temperature

Typical polarization curves measured in the cells are depicted in Fig. 2, at $30{ }^{\circ} \mathrm{C}$. Power density values were calculated by normalizing the power obtained in the cells to the anolyte volume $\left(2.3 \times 10^{-5} \mathrm{~m}^{3}\right)$. It can be observed that the three cells produced very similar polarization characteristics. Shape of both the power density and the voltage curves, however, is slightly different compared to the results obtained in twochambered MFCs in our previous studies (Tardy et al. 2017a, b), as a remarkable drop can be observed both in the power density and voltage at $\sim 0.6 \mathrm{~mA}$ current ( $\sim 600 \Omega$ external resistance). This phenomenon was observed in several previous studies (e.g. Min et al. 2008; Ieropoulos et al. 2010). The suggested explanation is mass transport limitations (e.g. proton transport in the PEM), or the so-called "power overshoot" theory: the depletion of ions and electrons in the anolyte as a result of the low external resistance (Ieropoulos et al. 2010).

Basic performance parameters of the cells (internal resistance; maximum power density; power density at $1000 \Omega$ external resistance) are depicted in Fig. 3 . These values were calculated from four polarization measurements carried out on four different days. Between the polarization measurements the MFCs were operated by applying $R_{e}=1000 \Omega\left(R_{e}\right.$ - external resistance).

Calculated average internal resistance values of the three cells were in the range of 610-660 $\Omega$, the standard deviation in each cell remained below $10 \%$ of the average value. Maximum power density averages of the cells (measured by applying the value of internal resistance as external resistance: $R_{e}=R_{i}$ ) were in the range of $958-1023 \mathrm{~mW} \mathrm{~m}^{-3}$, while power density 

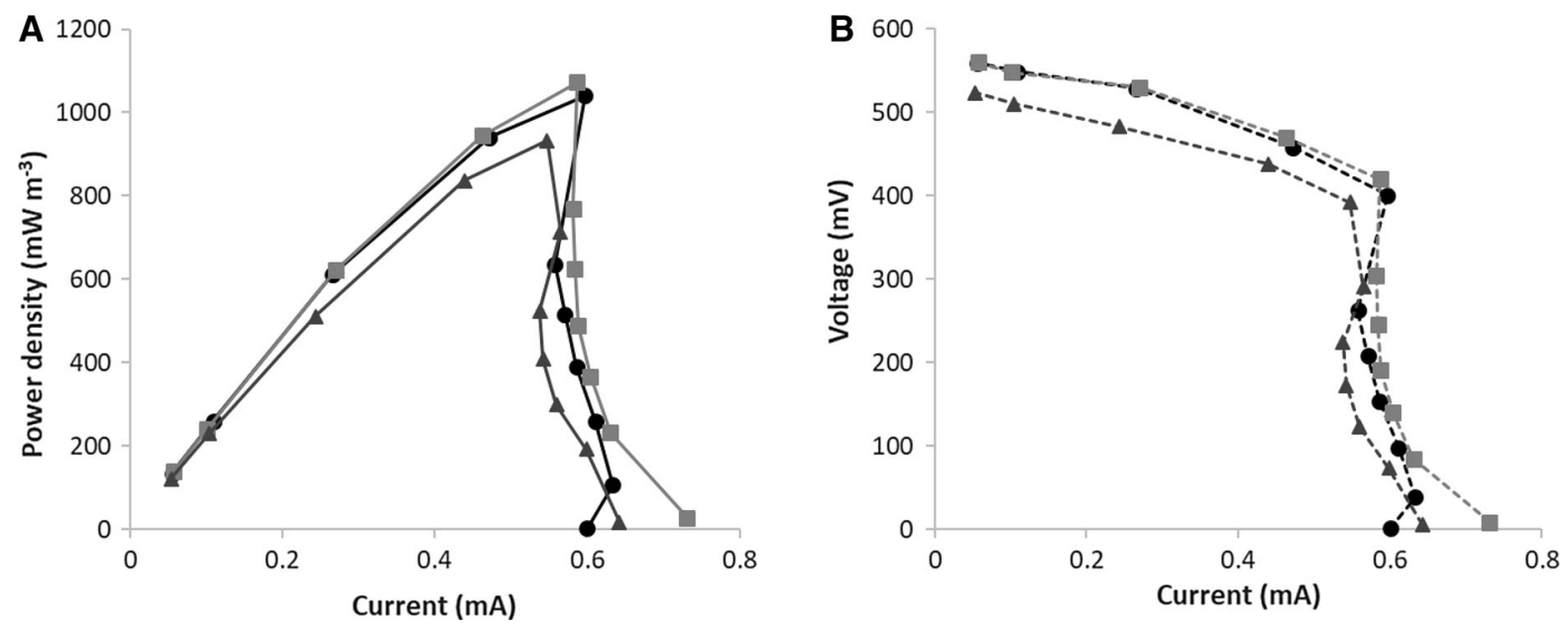

Fig. 2 Power density (a); Voltage (b) as a function of current in the three MFCs at $30{ }^{\circ} \mathrm{C} . \mathbf{a}, \mathbf{b}-\bullet-$ : Cell "A"; - $1-:$ Cell "B"; - $\mathbf{\Delta}-$ : Cell "C"

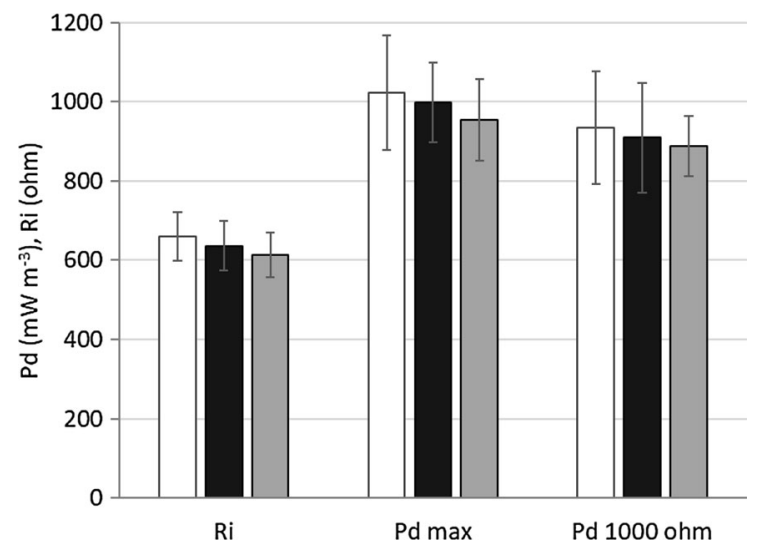

Fig. 3 Internal resistance $\left(\mathrm{R}_{\mathrm{i}}\right)$, maximum power density $\left(\mathrm{P}_{\mathrm{d}} \max \right)$ and power density measured at $1000 \Omega$ external resistance $\left(\mathrm{P}_{\mathrm{d} 1000 \Omega}\right)$ values obtained in the MFCs. $\square$ : MFC "A"; ㅁ: MFC "B”; : : MFC “C”

averages at $R_{e}=1000 \Omega$ were in the range of 887-933 $\mathrm{mW} \mathrm{m}^{-3}$. These values are in accordance with the values obtained for MFCs with similar design (Logan et al. 2015; Rahimnejad et al. 2015). No significant difference was observed $(\alpha=0.05)$ between the investigated cells for all of the three parameters, so the studied MFCs showed stable and similar operational characteristics. The investigated parameters were continuously monitored over the total $\sim 5$ months of experimental period and no considerable shift was observed.
Temperature dependence of current generation

In order to verify the effect of the temperature on the biodegradation rate, and as a result, on the generated current (see Eq. 1), the performance of the cells was investigated on 5 different temperatures $(15 ; 20 ; 25$; 30 and $35{ }^{\circ} \mathrm{C}$, respectively) applying $1000 \Omega$ external resistance (see Fig. 4). Highest current $(0.55 \pm 0.03 \mathrm{~mA})$ was observed at $30{ }^{\circ} \mathrm{C}$, however, with the calculated standard deviation, current values are not significantly different in the 25 to $35^{\circ} \mathrm{C}$ temperature range $(\alpha=0.05)$. At lower temperatures, the current generation drops, especially at $15{ }^{\circ} \mathrm{C}$ (to

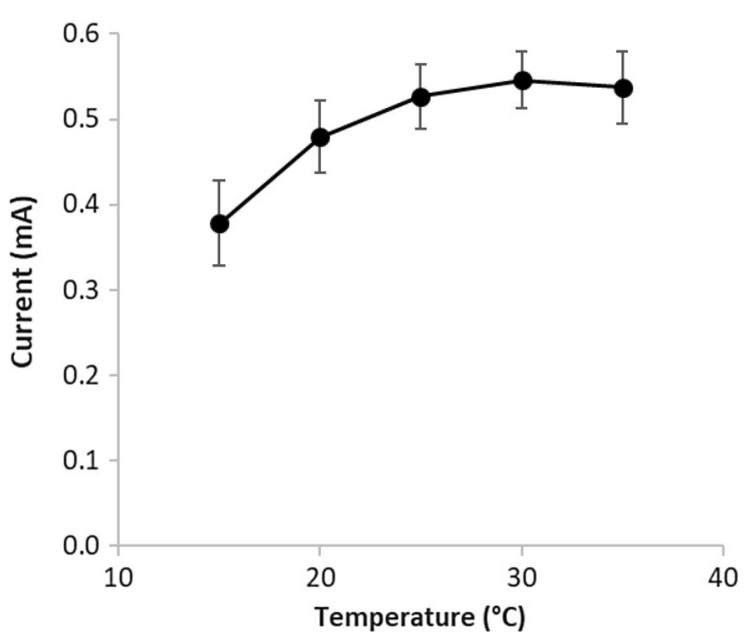

Fig. 4 Current generated in the cells (external resistance: 1000 $\Omega)$ as a function of operating temperature 
$0.38 \pm 0.05 \mathrm{~mA})$. It can be concluded that the temperature tolerance of the biomass in the MFC is mesophilic type, which is not surprising as the inoculation of the cells were carried out with basically mesophilic culture.

Concentration dependence of the current

Measurement of acetate concentration dependence of the current with stepwise substrate concentration increase was carried out with three different external resistance values $\left(\mathrm{R}_{\mathrm{e}}=100 \Omega ; 600 \Omega ; 1000 \Omega\right)$. Figure 5 shows the measured concentration values with a typical current vs. time curve in MFC " $\mathrm{A}$ " (with $\mathrm{R}_{\mathrm{e}}=600 \Omega$ ).

In order to predict the concentration of the acetate continuously during the experiment, assuming no biodegradation, a numeric hydraulic model was developed to use as a reference to measure the impact of biodegradation against. In this hydraulic model, we assumed that the concentration of the acetate in the anodic chambers is affected only by the hydraulics and dilution (the amount of acetate introduced through the influent and washed out with the effluent), the biodegradation during the experiment was neglected.

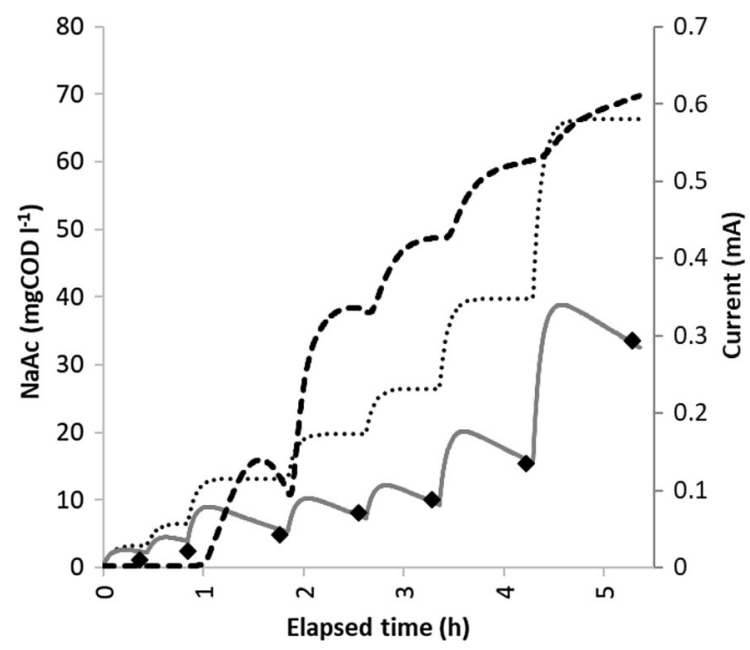

Fig. 5 Measured and modeled acetate concentrations and the obtained current as a function of time during the measurement of concentration dependence with $600 \Omega$ external resistance. $\downarrow$ : Acetate concentration measured with gas chromatography; An.. Acetate concentration calculated with the "hydraulic model"; - Acetate concentration calculated with the "biodegradation model"; - _ - Measured current in the external circuit of the MFC
By calculating the concentration value in every $20 \mathrm{~s}$ of the experiment, the hydraulic model showed the expected concentration steps (see Fig. 5, dotted line). Comparing the calculated concentration curve with the measured data, it is obvious that biodegradation has a strong effect on the actual acetate concentration in the anolyte. To be able to describe the concentration appropriately, the hydraulic model was complemented with the calculation of biodegradation of acetate with a Monod-kinetics based model. The acetate quantity removed by biodegradation over the $20 \mathrm{~s}$ time frame can be calculated by Eq. 2 .

$S_{\text {rem }}=r_{\max } \frac{S_{M F C}}{K_{s}+S_{M F C}} \Delta t$

where $S_{\text {rem }}$ is the removed acetate amount (mg COD), $\mathrm{S}_{\mathrm{MFC}}$ is the actual acetate concentration in the anode chamber (mg COD l$\left.~^{-1}\right), r_{\max }$ is the maximum acetate removal rate $\left(\mathrm{mg} \mathrm{COD} \mathrm{h}^{-1}\right)$ of the MFCs, $\mathrm{K}_{\mathrm{s}}$ is the half saturation constant (in the specific case depicted on Fig. 5 it is $6.7 \mathrm{mg}$ COD $1^{-1}$, see Table 1) and $\Delta \mathrm{t}=20 \mathrm{~s}$ equals to $5.55 \times 10^{-3} \mathrm{~h}$. $\mathrm{r}_{\max }$ was measured in the cells at high $\left(>2000 \mathrm{mg} \mathrm{COD}^{-1}\right)$ substrate concentrations, resulting in $3.6 \mathrm{mg} \mathrm{COD} \mathrm{h}^{-1}$ value per cell. Biodegradation was implemented in the preceding hydraulic model. Comparing the measured acetate concentrations with this "biodegradation model" results (see Fig. 5, grey line), it can be concluded that the elaborated model appropriately describes the acetate concentration in time (average difference between measured and modeled values is less than $2 \mathrm{mg} \mathrm{COD}^{-1}$ ).

Comparing the measured current values (see Fig. 5 dashed line) with the modeled acetate concentration values, it can be concluded that after the substrate deficient state, the exoelectrogenic biomass does not produce considerable current at extremely low acetate

Table 1 Parameters of the Monod-type concentration dependence model of the current

\begin{tabular}{lll}
\hline $\begin{array}{l}\mathrm{R}_{\mathrm{e}} \\
(\Omega)\end{array}$ & $\begin{array}{l}\mathrm{I}_{\max } \\
(\mathrm{mA})\end{array}$ & $\begin{array}{l}\mathrm{K}_{\mathrm{S}} \\
\left(\mathrm{mg} \mathrm{COD} \mathrm{^{-1 }}\right)\end{array}$ \\
\hline 100 & 1.29 & 8.2 \\
600 & 0.96 & 6.7 \\
1000 & 0.57 & 4.3 \\
\hline
\end{tabular}

$\mathrm{R}_{\mathrm{e}}$ : External resistance; $\mathrm{I}_{\max }$ : maximum current; $\mathrm{K}_{\mathrm{S}}$ : half saturation constant 
concentrations $\left(<5 \mathrm{mg} \mathrm{COD}^{-1}\right)$. Exceeding acetate concentration of $\sim 5 \mathrm{mg}$ COD $1^{-1}$ (third acetate dosage step), the current profile follows the stepwise concentration changes.

Depicting the obtained current values as a function of measured acetate concentrations at three different external resistance values $(100,600$ and $1000 \Omega$, respectively, see Fig. 6) supports the assumption that acetate concentration dependence of the current follows Monod-like kinetics (see Eq. 1). Monod curves were fitted to the measurement results, the obtained maximum current and half saturation constant values are summarized in Table 1. Current depends on the external resistance, so $I_{\max }$ values increase with the decreasing $R_{e}$ values. Although, by decreasing the external resistance $K_{S}$ values slightly increased, even in case of the lowest $100 \Omega$ external resistance, the half saturation constant remained below $10 \mathrm{mg} \mathrm{COD}^{-1}$. With $100 \Omega$ of $\mathrm{R}_{\mathrm{e}}$, baseline current of the substrate free state is $20 \pm 3 \mu \mathrm{A}$ (originating from the endogenous metabolism). Measurements showed that acceptable signal strength for detection (higher than $30 \mu \mathrm{A}$ ) occurred typically at $\geq 5 \mathrm{mg} \operatorname{COD~}^{-1}$ concentration, thus this value can be considered as detection limit of this measurement. As a result of the low $\mathrm{K}_{\mathrm{S}}$ value, considerable concentration dependence of the current can be observed only in the range of low

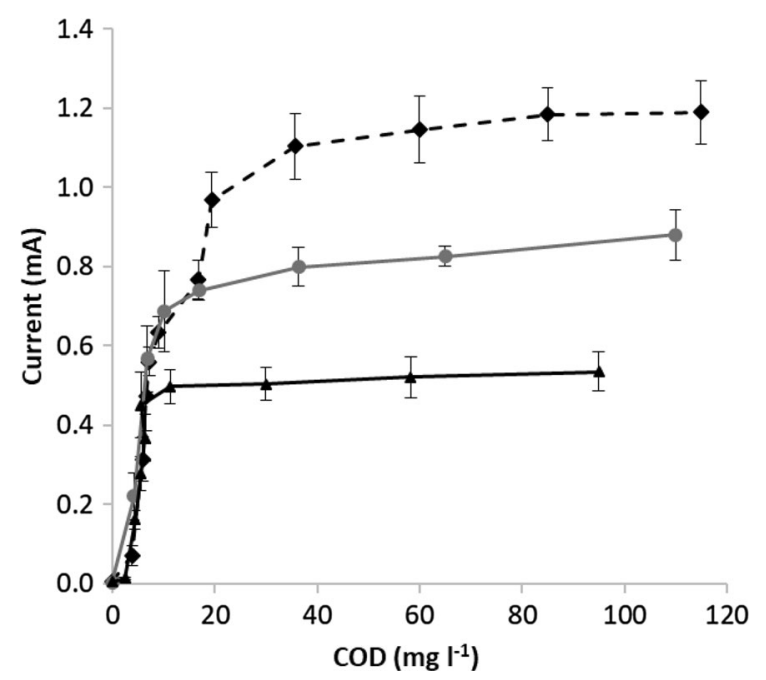

Fig. 6 Obtained average current of the operated 3 MFCs with the standard deviation as a function of acetate concentration at three different external resistance $(\mathrm{Re})$ values. $100 \Omega$ external resistance; - -: $600 \Omega$ external resistance; - $\Delta$-: $1000 \Omega$ external resistance acetate concentrations ( $<40 \mathrm{mg} \mathrm{COD}^{-1}$, see Fig. 6), where the sensitivity of the cell provides higher than 5 $\mu \mathrm{A}$ current change per mg COD $1^{-1}$ substrate concentration change. At higher substrate concentrations, the sensitivity decreases and above $70 \mathrm{mg}$ COD $1^{-1}$ current becomes practically independent from the acetate concentration (current obtained at $70 \mathrm{mg}$ COD $1^{-1}$ acetate concentration is higher than $90 \%$ of the $\mathrm{I}_{\text {max }}$ value).

In order to investigate the concentration dependence with a complex substrate at $100 \Omega$ external resistance, the measurement was repeated by using peptone (Molar Chemicals) as carbon source instead of acetate. Comparing the measured current values (see Fig. 7), it can be concluded that the shape of the curves is similar for the synthetic (acetate based) and the complex (peptone based) media. Kinetic parameter

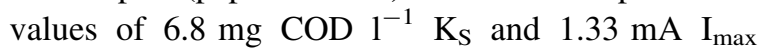
calculated by fitting Monod-curves to the measured current values obtained for peptone based media confirm the suggestion that biodegradation of the complex peptone-based media occurring with practically the same kinetics as the synthetic acetate.

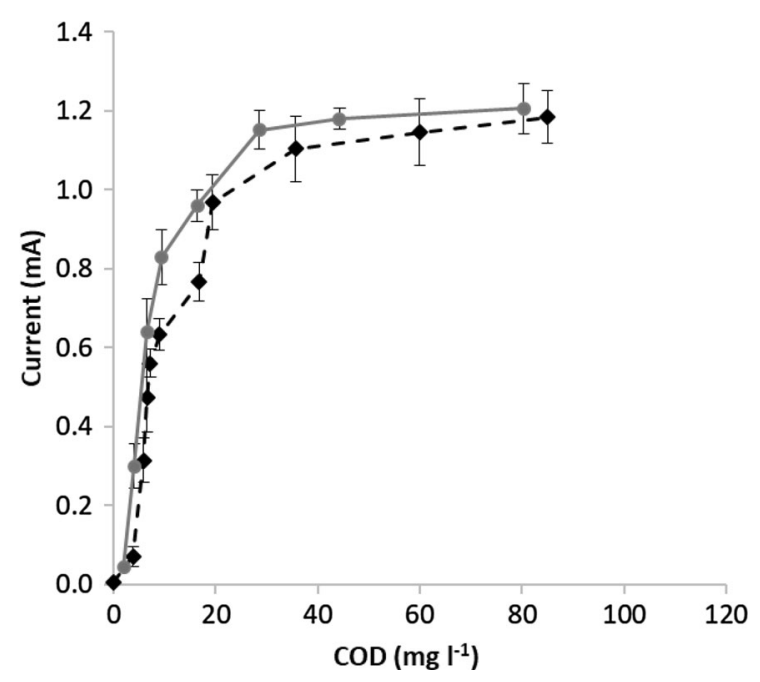

Fig. 7 Obtained average current of the operated 3 MFCs with the standard deviation as a function of COD concentration of the media with acetate and peptone as carbon source. - Acetate based media; - -: Peptone based media 


\section{Conclusions}

Single chamber air cathode microbial fuel cells were investigated for application as biosensors for the determination of biodegradable organics concentration. The MFCs with the applied biomass originated cathode material and with the developed design operated with a steady and well-reproducible performance at high (> $2000 \mathrm{mg} \mathrm{COD}^{-1}$ ) acetate concentrations, providing an average of $1014 \mathrm{~mW} \mathrm{~m}^{-3}$ maximum power density and higher than $0.5 \mathrm{~V}$ potential and $0.5 \mathrm{~mA}$ current, guaranteeing appropriate signal strength for biosensor application at $1000 \Omega$ external resistance.

Inoculating with mesophilic biomass originated from pre-clarified sludge of a domestic wastewater treatment plant, stable current was observed in the range of $25-35{ }^{\circ} \mathrm{C}$ temperature range. Below this range at $15{ }^{\circ} \mathrm{C}$, however, the biodegradation rate (and as a result, the current) in the MFCs decreased significantly. Based on this result, it can be suggested, that if biosensors with this MFC design are operated in non-thermostated environment, the effect of the temperature has to be taken into consideration (e.g. temperature dependent calibration has to be carried out) for the appropriate operation, especially below $20{ }^{\circ} \mathrm{C}$.

Acetate concentration dependence of the current obtained in the MFCs showed the expected Monodtype relationship. Decreasing the external resistance from $1000 \Omega$ to $100 \Omega$ caused an increase (from 0.57 to $1.29 \mathrm{~mA}$ ) in the $\mathrm{I}_{\max }$ values. Half saturation constant, however, remained below $10 \mathrm{mg} \mathrm{COD}^{-1}$ with all the investigated external resistance values. Concentration dependence of the current showed similar characteristics by applying peptone as complex carbon source instead of acetate.

Results suggest that biosensors with the investigated MFC design and operation are potentially applicable for detecting as low as $5 \mathrm{mg}$ COD $1^{-1}$ readily biodegradable substrates, and the concentration of these substances can be calculated directly from current up to $\sim 50-70 \mathrm{mg} \mathrm{COD} 1^{-1}$ in natural waters or wastewater treatment plant effluents.

Acknowledgements Open access funding was provided by Budapest University of Technology and Economics (BME). The research was carried out in the frames of the collaborative research program of Budapest University of Technology and Economics and Okinawa Institute of Science and Technology
Graduate University entitled "Investigation and development of microbial fuel cell based water/wastewater treatment technologies for nitrogen and carbon removal". We would like to express our thanks to Prof. József Balla and his research group for the $\mathrm{GC}$ measurements.

Open Access This article is distributed under the terms of the Creative Commons Attribution 4.0 International License (http:// creativecommons.org/licenses/by/4.0/), which permits unrestricted use, distribution, and reproduction in any medium, provided you give appropriate credit to the original author(s) and the source, provide a link to the Creative Commons license, and indicate if changes were made.

\section{References}

Abrevaya XC, Sacco NJ, Bonetto MC, Hilding-Ohlsson A, Cortón E (2015a) Analytical applications of microbial fuel cells. Part I: biochemical oxygen demand. Biosens Bioelectron 63:580-590. https://doi.org/10.1016/j.bios.2014. 04.034

Abrevaya XC, Sacco NJ, Bonetto MC, Hilding-Ohlsson A, Cortón E (2015b) Analytical applications of microbial fuel cells. Part II: toxicity, microbial activity and quantification, single analyte detection and other uses. Biosens Bioelectron 63:591-601. https://doi.org/10.1016/j.bios.2014.04. 053

Di Lorenzo M, Thomson AR, Schneider K, Cameron PJ, Ieropoulos I (2014) A small-scale air-cathode microbial fuel cell for on-line monitoring of water quality. Biosens Bioelectron 62:182-188. https://doi.org/10.1016/j.bios.2014. 06.050

Divyalakshmi P, Murugan D, Rai CL (2017) Influence of diligent disintegration on anaerobic biomass and performance of microbial fuel cell. Biotechnol Lett 39:1883-1888. https://doi.org/10.1007/s10529-017-2420-4

Fedorovich V, Varfolomeev SD, Sizov A, Goryanin I (2009) Multi-electrode microbial fuel cell with horizontal liquid flow. Water Sci Technol 60:347-355. https://doi.org/10. 2166/wst.2009.139

Ieropoulos I, Winfield J, Greenman J (2010) Effects of flow-rate, inoculum and time on the internal resistance of microbial fuel cells. Bioresour Technol 101:3520-3525. https://doi. org/10.1016/j.biortech.2009.12.108

Logan BE, Wallack MJ, Kim KY, He W, Feng Y, Saikaly PE (2015) Assessment of microbial fuel cell configurations and power densities. Environ Sci Technol Lett 2:206-214. https://doi.org/10.1021/acs.estlett.5b00180

Lóránt B, Lóka M, Tardy GM (2015) Substrate concentration dependency of electricity production in microbial fuel cells. IEEE Xplore. In: Proceedings of the IYCE 2015, Pisa, pp 1-7. https://doi.org/10.1109/iyce.2015.7180786

Min B, Román ÓB, Angelidaki I (2008) Importance of temperature and anodic medium composition on microbial fuel cell (MFC) performance. Biotechnol Lett 30:1213-1218. https://doi.org/10.1007/s10529-008-9687-4

Oh S, Min B, Logan BE (2004) Cathode performance as a factor in electricity generation in microbial fuel cells. Environ Sci 
Technol 38:4900-4904. https://doi.org/10.1021/ es049422p

Quek SB, Cheng L, Cord-Ruwisch R (2015) Microbial fuel cell biosensor for rapid assessment of assimilable organic carbon under marine conditions. Water Res 77:64-71. https:// doi.org/10.1016/j.watres.2015.03.012

Rahimnejad M, Adhami A, Darvari S, Zirepour A, Oh S-E (2015) Microbial fuel cell as new technology for bioelectricity generation: a review. Alexandria Eng J 54:745-756. https://doi.org/10.1016/j.aej.2015.03.031

Schaffer-Harris GK, Fedorovich V, Goryanin I, Szydlowski L, Simpson DJW, Filonenko G (2017) Process for preparing a supported catalytic material based on reduction of transition metals and supported catalytic material. International Application No.: PCT/JP2018/007294

Sharma Y, Li B (2010) The variation of power generation with organic substrates in single-chamber microbial fuel cells (SCMFCs). Bioresour Technol 101:1844-1850. https:// doi.org/10.1016/j.biortech.2009.10.040

Sun JZ, Kingori GP, Si RW, Zhai DD, Liao ZH, Sun DZ, Zheng T, Yong YC (2015) Microbial fuel cell-based biosensors for environmental monitoring: a review. Water Sci Technol 71:801-809. https://doi.org/10.2166/wst.2015.035

Tardy GM, Lóránt B, Lóka M (2017a) Substrate concentration dependence of voltage and power production characteristics in two-chambered mediator-less microbial fuel cells with acetate and peptone substrates. Biotechnol Lett 39:383-389. https://doi.org/10.1007/s10529-016-2256-3

Tardy GM, Lóránt B, Lóka M, Nagy B, László K (2017b) Enhancing substrate utilization and power production of a microbial fuel cell with nitrogen-doped carbon aerogel as cathode catalyst. Biotechnol Lett 39:993-999. https://doi. org/10.1007/s10529-017-2338-x

Tront JM, Fortner JD, Plötze M, Hughes JB, Puzrin AM (2008) Microbial fuel cell bio-sensor for in situ assessment of microbial activity. Biosens Bioelectron 4:586-590. https:// doi.org/10.1016/j.bios.2008.06.006

Publisher's Note Springer Nature remains neutral with regard to jurisdictional claims in published maps and institutional affiliations. 